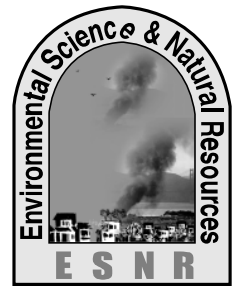

J. Environ. Sci. \& Natural Resources, 5(2): 231- 237, 2012

ISSN 1999-7361

\title{
Metals and Histopathological Alterations in the Liver of Schizothorax niger, Heckel From The Dal Lake of Kashmir Valley
}

\author{
${ }^{1}$ R. Yousuf, ${ }^{1}$ S. H. Mir, S. Tanveer ${ }^{1}$, M. M. Darzi ${ }^{2}$ and ${ }^{2}$ M. S. Mir \\ ${ }^{1}$ Department of Zoology, University of Kashmir, Srinagar-190 006 \\ ${ }^{2}$ Department of Pathology, FVSC \& AH, Shuhama Alustend (SKUAST-K), Srinagar- 190006
}

\begin{abstract}
The study was conducted to evaluate the metal induced abnormalities in the liver of Schizothorax niger from Dal Lake seasonally for a period of two years. The varied seasonal metal concentrations for copper (66.77 \pm 3.12 to $81.68 \pm 3.51 \mathrm{ppm})$, zinc (73.81 \pm 2.52 to $97.84 \pm 4.62 \mathrm{ppm})$, iron $(204.92 \pm 5.21$ to $296.51 \pm 4.37 \mathrm{ppm})$ and manganese $(01.13 \pm 0.02$ to $08.30 \pm 1.00 \mathrm{ppm})$ were observed during the entire period of study. The highest concentration of metals was observed in the summer seasons and the lowest concentrations in the winter seasons during the study period. Further, histochemical analysis demonstrated enormous amount of metals $(\mathrm{Cu}, \mathrm{Fe}$ and $\mathrm{Zn})$ in the liver of Schizothorax niger in summer seasons during the entire study period. The subsequent effects of metals, demonstrated by wet digestion-based Atomic Absorption Method and histochemical methods showed histological changes on the liver of Schizothorax niger. The liver showed disruption of the hepatic cords with congestion and degenerative changes in hepatocytes that varied from mild in winter seasons to severe vascular degeneration in summer season. From the present study it may be concluded that the metals in the environment are polluting the water bodies and their subsequent deleterious effects harm the aquatic fauna particularly the sensitive native fish, Schizothorax niger which is one of the reasons for its decline from the fresh water resources of the Kashmir Valley.
\end{abstract}

Key Words: Histology, Liver, Metals, Schizothorax niger

\section{Introduction}

The varieties of human activities acting upon the natural environment result in the release of different chemicals including metals. The sources of metals include commercial fertilizers, sewage sludge's, urban wastes, liming material and agrochemicals and other wastes used as soil amendments (Rao, 1998). The exposure of bio-organisms to metals can cause long-term and non-reversible effects (Cheng, 2003). Fish species are widely used to biologically monitor variation in environmental levels of anthropogenic pollutants (Whyte et al., 2000; Schmitt, 2004).

The liver is an important organ involved in metabolic processes and in detoxification of xenobiotics. In some situations, materials may accumulate in the liver to toxic levels and cause pathological alterations (Meyers and Hendricks, 1985; Ferguson, 1989; Braunbeck et al., 1990). The liver not only represents a central organ concerning basic metabolism (Gingerich, 1982), but is also a major site of the accumulation, biotransformation and excretion of xenobiotic compounds (Meyers and Hendricks, 1985). It is the first organ to be exposed by the portal circulation to toxicants ingested by the body (Hibiya, 1982). Because of its unique position and proximity to the venous drainage of the digestive tract, the liver is susceptible to damage from absorbed toxic materials (Leeson and Leeson, 1976). The high degree of metabolic activity of hepatocytes renders them vulnerable and toxins can easily affect them. The harmful effects of ingested toxic substances are primarily exerted within the liver cells (Lloyd, 1992). Subsequently, hepatocytes respond to changes in the external and internal environments by alterations in both cellular structure and function (Wheater et al., 1985). Since histopathological alterations are recognized and commonly used diagnostic tools in fish toxicological studies (Lloyd, 1992) the present study was designed to study the metal-induced toxicity to liver of Schizothorax niger in naturally occurring water body of Dal Lake.

\section{Materials and Methods}

\section{Collection of Fish Hosts}

Fishes were collected from the Dal Lake with the help of local fishermen and were brought alive in plastic buckets to the laboratory for investigating the different parameters.

\section{Species and number of fish used}

The study was conducted on Schizothorax niger, Heckel. Pooled specimens were collected from the collection sites of the Dal Lake so as to make a sample size of 25 fish (of either sex) with an average length of 30-40 cms. The study was repeated for each season for the year-I and again during Year-II.

\section{Seasonal classification}

The study was conducted in four seasons annually, each with a duration of 3 months. The four seasons included Spring (March-May), Summer (JuneAugust), Autumn (September-November) and Winter (December-February). 


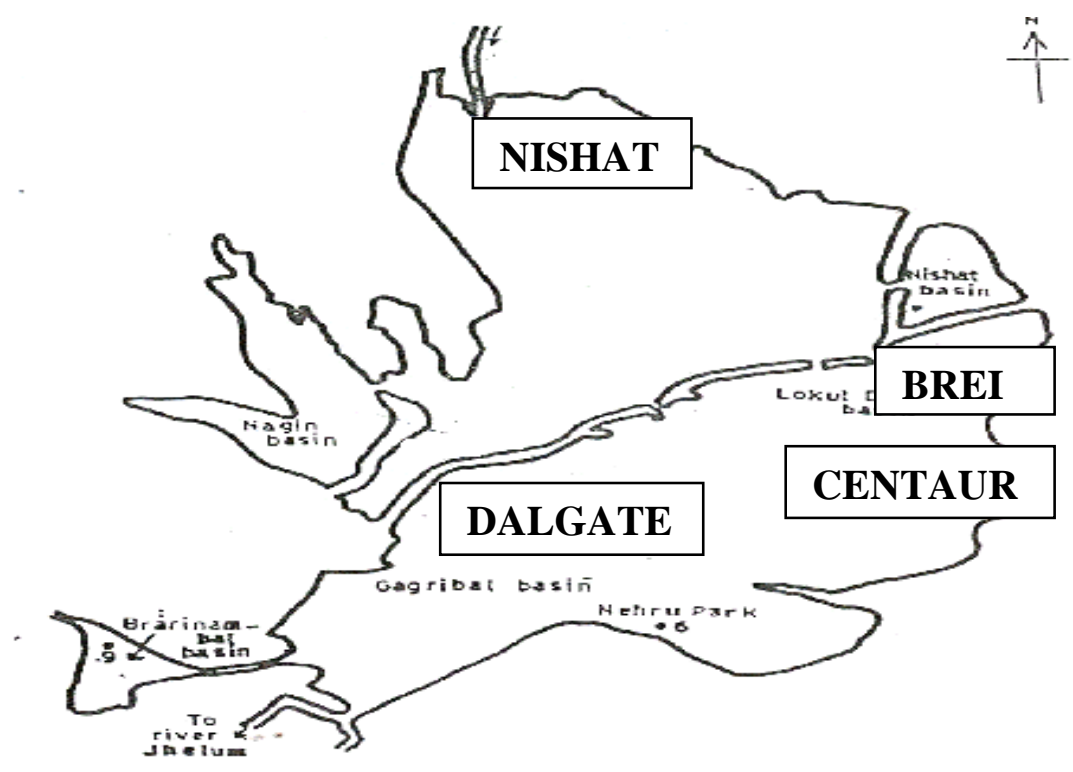

Fig. 1: Map of Dal Lake showing different collection sites such as Site I (Dalgate), Site II (Centaur), Site III (Brein) and Site IV (Nishat)

\section{Metal analysis of water}

For detection of metals in water, the samples were collected in conical flasks, filtered through Whatman's filter paper and processed in Atomic Absorption Spectrophotometer (AAS) for estimation of various metal concentrations employing Lindsay and Norwell Method (1978).

\section{Histochemical demonstration of metals}

For detection of metals viz copper, iron and zinc in fish gills different histochemical methods such as Perl's method for Iron; Dithiooxamide method for copper; Dithizone method for zinc etc (Luna, 1968) were used so as to ensure metal induced toxicity specify the manganese detection method.

\section{Histological procedure}

Histological examination was done after fixing the fishes in $10 \%$ formalin, processed and embedded in paraffin wax. Tissue blocks were sectioned $5 \mu \mathrm{m}$ thick and stained with Harris haematoxylin and eosin (H\&E) (Luna 1968).

\section{Results}

\section{Metal concentrations in water}

In Dal Lake the concentration of copper was in the range of 1.020 to $1.070 \mathrm{ppm}$, with maximum concentration found in summer season (year-II) and the minimum in winter season (year-I). The iron concentration ranged between 0.110 to $0.191 \mathrm{ppm}$. The highest value was observed during summer season (year-II) and the minimum in winter season (year-I). The zinc concentration ranged between 0.150 to $0.542 \mathrm{ppm}$, with maximum value observed in summer season (year-II) and the lowest values in winter season (year-I). The manganese concentration ranged between 0.021 to $0.083 \mathrm{ppm}$ with maximum value observed in summer season year-II and the lowest values in winter season (year-I).

\section{Metal concentrations in the liver}

In Schizothorax niger, the mean concentration of copper in the liver ranged from $66.77 \pm 3.12$ to 81.68 $\pm 3.51 \mathrm{ppm}$ (Table I). The maximum value of $81.68 \pm$ $3.51 \mathrm{ppm}$ was observed in summer (year-II) and the lowest value of $66.77 \pm 3.12$ was observed in winter season (year-I).

The concentration of zinc in the liver was $73.81 \pm$ 2.52 to $97.84 \pm 4.62 \mathrm{ppm}$ (Table II). The maximum value of $97.84 \pm 4.62 \mathrm{ppm}$ was observed in the summer season of year-II and the minimum value of $73.81 \pm 2.52 \mathrm{ppm}$ was observed in the winter seasons of year-I.

The concentration of iron in liver varied between $204.92 \pm 5.21$ to $296.51 \pm 4.37 \mathrm{ppm}$ (Table III). The maximum values of $296.51 \pm 4.37 \mathrm{ppm}$ in liver was 
observed in the summer (year-II) and the minimum values of $204.92 \pm 5.21 \mathrm{ppm}$ in liver was observed in the winter season (year-I).

The concentration of manganese in liver ranged between $01.13 \pm 0.02$ to $08.30 \pm 1.00 \mathrm{ppm}$ (Table VI). The highest values of $08.30 \pm 1.00 \mathrm{ppm}$ in liver was observed in summer season of year-II. The lowest value of $01.13 \pm 0.02 \mathrm{ppm}$ in liver was observed in the spring season of the year-I.

\section{Histological changes}

The liver showed disruption of the hepatic cords and tubules with congestion and degenerative changes in hepatocytes that varied from mild in winter seasons to severe hapataytic?degeneration in summer season (Fig. 2-3). Further, kupffer cell hyperplasia was noticed in the liver of Schizothorax niger (Fig. 3).

Table 1: Showing Copper concentration in the liver of Schizothorax niger in different season of the study period in Dal Lake

\begin{tabular}{|c|c|c|c|c|c|c|c|}
\hline \multirow{2}{*}{$\begin{array}{c}\text { Water } \\
\text { resources }\end{array}$} & Fish Host & Year & $\begin{array}{c}\text { No. } \\
\text { Observed }\end{array}$ & \multicolumn{4}{|c|}{ Copper accumulation (ppm) } \\
\cline { 5 - 8 } & & I & 25 & $70.01 \pm 2.12$ & $76.52 \pm 2.81$ & $\begin{array}{c}68.52 \pm \\
2.12\end{array}$ & $\begin{array}{c}66.77 \pm \\
3.12\end{array}$ \\
\cline { 5 - 8 } Dal Lake & $\begin{array}{c}\text { Schizothorax } \\
\text { niger }\end{array}$ & II & 25 & $74.54 \pm 3.24$ & $81.68 \pm 3.51$ & $\begin{array}{c}72.82 \pm \\
3.24\end{array}$ & $\begin{array}{c}70.54 \pm \\
3.12\end{array}$ \\
\hline
\end{tabular}

Values are expressed as mean \pm SEM

Table 2: Showing zinc concentration in the gills of Schizothorax niger in different season of the study period in Dal Lake

\begin{tabular}{|c|c|c|c|c|c|c|c|}
\hline \multirow{2}{*}{$\begin{array}{c}\text { Water } \\
\text { resources }\end{array}$} & \multirow{2}{*}{ Fish Host } & \multirow{2}{*}{ Year } & \multirow{2}{*}{$\begin{array}{c}\text { No. } \\
\text { Observed }\end{array}$} & \multicolumn{4}{|c|}{ Zinc accumulation (ppm) } \\
\hline & & & & Spring & Summer & Autumn & Winter \\
\hline \multirow{2}{*}{ Dal Lake } & \multirow{2}{*}{$\begin{array}{l}\text { Schizothorax } \\
\text { niger }\end{array}$} & I & 25 & $74.52 \pm 2.24$ & $90.61 \pm 3.92$ & $\begin{array}{c}75.12 \pm \\
4.77 \\
\end{array}$ & $\begin{array}{c}73.81 \pm \\
2.52 \\
\end{array}$ \\
\hline & & II & 25 & $81.06 \pm 3.44$ & $97.84 \pm 4.62$ & $\begin{array}{c}82.52 \pm \\
3.99\end{array}$ & $\begin{array}{c}80.88 \pm \\
4.15\end{array}$ \\
\hline
\end{tabular}

Values are expressed as mean \pm SEM

Table 3: Showing iron concentration in the liver of Schizothorax niger in different Season of the study period in Dal Lake

\begin{tabular}{|c|c|c|c|c|c|c|c|}
\hline \multirow{2}{*}{$\begin{array}{c}\text { Water } \\
\text { resources }\end{array}$} & \multirow{2}{*}{ Fish Host } & \multirow{2}{*}{ Year } & \multirow{2}{*}{$\begin{array}{c}\text { No. } \\
\text { Observed }\end{array}$} & \multicolumn{4}{|c|}{ Iron accumulation (ppm) } \\
\hline & & & & Spring & Summer & Autumn & Winter \\
\hline \multirow{2}{*}{ Dal Lake } & \multirow{2}{*}{$\begin{array}{c}\text { Schizothorax } \\
\text { niger }\end{array}$} & I & 25 & $\begin{array}{c}227.91 \pm \\
6.52 \\
\end{array}$ & $284.31 \pm 4.29$ & $\begin{array}{c}228.36 \pm \\
6.55 \\
\end{array}$ & $\begin{array}{r}204.92 \pm \\
5.21 \\
\end{array}$ \\
\hline & & II & 25 & $\begin{array}{c}241.20 \pm \\
\quad 6.96\end{array}$ & $296.51 \pm 4.37$ & $\begin{array}{c}242.54 \pm \\
4.85\end{array}$ & $\begin{array}{c}234.56 \pm \\
5.95\end{array}$ \\
\hline
\end{tabular}

Values are expressed as mean \pm SEM 
Table 4: Showing manganese concentration in the liver of Schizothorax niger in different season of the study period in Dal Lake

\begin{tabular}{|c|c|c|c|c|c|c|c|}
\hline \multirow{2}{*}{$\begin{array}{c}\text { Water } \\
\text { resources }\end{array}$} & \multirow{2}{*}{ Fish Host } & \multirow{2}{*}{ Year } & \multirow{2}{*}{$\begin{array}{c}\text { No. } \\
\text { Observed }\end{array}$} & \multicolumn{4}{|c|}{ Manganese accumulation (ppm) } \\
\hline & & & & Spring & Summer & Autumn & Winter \\
\hline \multirow{2}{*}{ Dal Lake } & \multirow{2}{*}{$\begin{array}{l}\text { Schizothorax } \\
\text { niger }\end{array}$} & I & 25 & $01.13 \pm 0.02$ & $07.13 \pm 0.99$ & $\begin{array}{c}03.16 \pm \\
0.98\end{array}$ & $\begin{array}{l}02.81 \pm \\
0.05\end{array}$ \\
\hline & & II & 25 & $02.74 \pm 0.03$ & $08.30 \pm 1.00$ & $\begin{array}{c}04.74 \pm \\
0.11\end{array}$ & $\begin{array}{l}03.55 \pm \\
0.07\end{array}$ \\
\hline
\end{tabular}

Values are expressed as mean \pm SEM

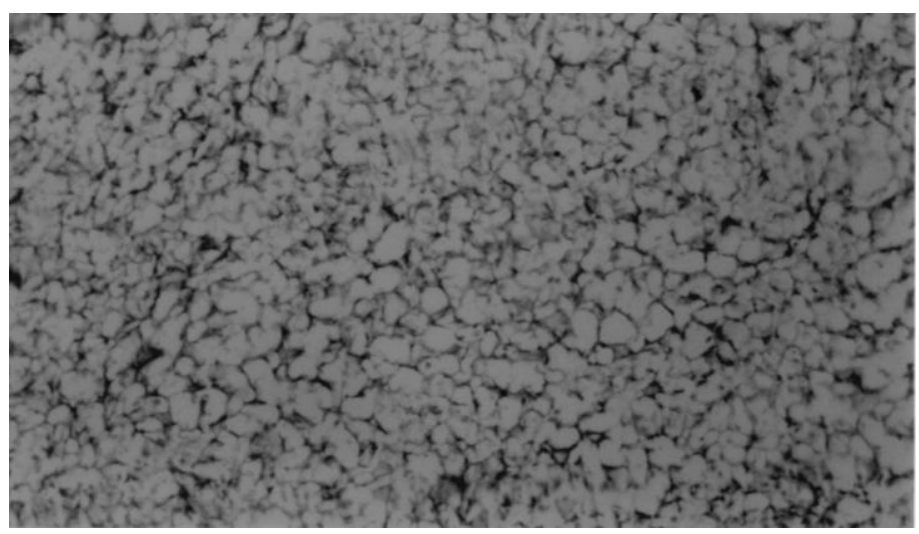

Fig 2: showing severe congestion and degenerative changes in hepatocytes $(\times 100 \mathrm{X})$.

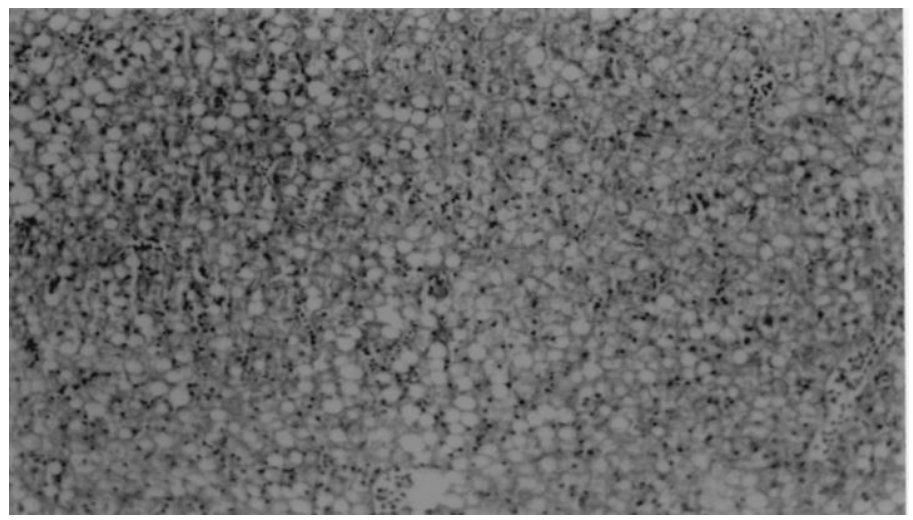

Fig 3: showing kupffer cell hyperplasia in the liver ( $\times 100 \mathrm{X})$.

\section{Discussion}

In Dal Lake the concentration of copper was in the range of 1.020 to $1.070 \mathrm{ppm}$; iron 0.110 to $0.191 \mathrm{ppm}$; zinc 0.150 to $0.542 \mathrm{ppm}$ and manganese 0.021 to $0.822 \mathrm{ppm}$. Metal accumulations can be attributed to a variety of sources- such as from rocks, solids, dead and decomposing vegetation, wet and dry fallout of atmospheric particulate matter and from human activities including the discharge of various treated and untreated liquid wastes into the water bodies (Lasheen, 1987). The concentration of metals in the Dal Lake water can be attributed to its stagnant waters. Seasonal differences were also observed with higher concentrations during the summers, followed by spring, autumn and winter. This may be due to higher fallout of metals from the decomposing matter and increase in temperature during the hot seasons, which gradually reduce during the colder months. 
Further, it is generally accepted that heavy metal uptake occurs mainly from water, food and sediment (bottom feeders and burrowing animals) (Canli et al., 1998). However, the metal uptake from water is much higher than uptake from sediment (Mance, 1987; Langston, 1990; Merian, 1991). It may be emphasised, that the efficiency of metal uptake from contaminated water and food may differ in relation to ecological needs, metabolism and the contamination gradients of water and food and sediment, as well as other factors such as salinity, temperature and interacting agents (Pagenkopf, 1983; Cusimano et al., 1986; Heath, 1987; Canli and Furness, 1993; Goyer, 1991; Canli and Furness, 1995). Years-wise data showed a higher heavy metal concentration in the latter year than the preceding in both water bodies. This clearly suggested an increase in pollution levels in the water body.

Season-wise higher tissue concentrations of heavy metals were observed in summer with decline in their levels during spring, autumn and winter in a decreasing order. Obviously, the progressive increase in the metal levels in the tissues coincides with the period of rising temperatures during summer. It is generally accepted that metal accumulation in living organisms is largely controlled by specific uptake, detoxification and elimination mechanisms and therefore depends significantly on the season (Cogun et al., 2006). Seasonal differences in the heavy metal accumulation in fish can be related to their metabolic rate, which determines the physiological condition of fish (Farkas et al., 2003). Laboratory experiments have shown that changes in temperature can affect the increase or decrease of heavy metal concentrations because of changes in metabolic and excretion rates (Hilmy et al., 1987; Yang and Chen, 1996). The copper was found to be greater in amount in the fish tissues during the present research study and can be attributed to the fact that it has a tendency to accumulate to a greater extent than other essential elements, such as zinc and iron (Heath, 1987; Roesijadi and Robinson, 1994). Fish are naturally exposed to a variety of metals including both essential and non-essential elements. Copper is one of the essential metals that after absorption from gills and intestines is transported by metallothionein into the blood circulation and some of it accumulates in different internal organs specially liver and kidneys (Peyghan et al., 2003).

It is generally accepted that metal accumulation in tissues of aquatic animals is dependent upon exposure concentration and period as well as some other factor such as salinity, temperature, interacting agents and metabolic activity of tissue in concern. Similarly, it is also known that metal accumulation in tissues of fish is dependent upon the rate of uptake, storage and elimination (Health, 1987; Langston, 1990; Roesijadi and Robisnson, 1994).

In terms of zinc toxicity, the concentrations of the metal within certain tissue may be associated with mortalities (Zitko, 1979) and sub lethal effects such as behavioral and physiological disruptions (Buikema et al., 1982). The analysis of the zinc in different tissues of fish hosts observed in the present study during different seasons showed higher concentration in summer. These observations are similar to findings of Velcheva (2006), who reported higher zinc content in summer and autumn than spring and winter in the water and fish tissue of both Kardjali and Studen Kladenets dam lakes in Bulgaria. Other studies have shown that zinc possesses affinity to protein sulfhydryl groups and its increased load in the kidneys and liver lead to a release of a specific metal protein, metallothioneine from these organs (Cosson, 1994; Vilella et al., 1999).

Fish acquire iron predominantly from the diet and its uptake varies in different organs (Andersen, 1997; Bury et al., 2001). The highest concentration of iron in liver observed in the present study can be attributed to the fact that liver is the main storage pool for iron in fish (Van Dijk et al., 1975; Walker and Fromm, 1976). Further studies have shown that liver, which is a major producer of metal-binding proteins, show high concentration of metals (Roesijadi and Robinson, 1994; Allen, 1994).

Manganese, which is required in trace amounts by the fish hosts, was found to be predominant in summer followed by autumn, spring and winter in both fishes. Excess external concentration of manganese in the medium could lead to high internal levels and thereby interfering with enzymatic activity or other metabolic functions (Gonzalez et al., 1990). However, its concentration was found to be lower than other observed metals viz. copper, iron and zinc. This can be attributed to the fact that fish can regulate the amount of manganese in their body (Kwasnik et al., 1978).

\section{References}

Allen, P. 1994. Accumulation profiles of lead and the influence of cadmium and mercury in Oreochromis aureus (Steindachner) during

chronic exposure. Toxic. Environ. Chem., 44: 101-112.

Andersen, O. 1997. Accumulation of waterborne iron and expression of ferritin and transferrin in 
early developmental stages of brown trout (Salmo trutta). Fish Physiol. Biochem., 16: 223-231.

Braunbeck, T.; Storch, V. and Breshch, H. 1990. Species-specific reaction of liver ultrastucture in zebrafish (Brachydanio rerio) and trout (Salmo gairdneri) after prolonged exposre to 4- chloraniline. Arch. Environ. Contam. Toxicol., 19: 405-418.

Buikema, A. L.; Jr.; Niederlehner, B. R. and Cairns, J. 1982. Biological monitoring. Part IV. Toxicity testing. Wat. Res., 16: 239-262.

Bury, N. R.; Grosell, M.; Wood, C. M.; Hogstrand, C.; Wilson, R. W.; Rankin, J. C.; Busk, M.; Lecklin, T. and Jensen, F. B. 2001. Intestinal iron uptake in the European flounder (Platichthys flesus). J. Exp. Biol. 204: 37793787.

Canli, M. A and Furness, R. W. 1993. Toxicity of heavy metals dissolved in sea water and influences of sex and size on metal accumulation and tissue distribution in the Norway lobstwr Nephrops norvegicus. Mar. Environ. Res., 36: 217-236.

Canli, M. and Furness, R. W. 1995. Mercury and cadmium uptake from seawater and from food by the Norway lobster Nephrops norvegicus. Environ. Toxicol. Chem., 14: 819-828.

Canli, M.; Ay, O. and Kalay, M. 1998. Levels of heavy metals $(\mathrm{Cd}, \mathrm{Pb}, \mathrm{Cu}, \mathrm{Cr}$ and $\mathrm{Ni})$ in tissues of Cyprinus carpio, Barbus capito and Chandrostoma regium from the Seyhan River, Turkey. Turkm J. Zool., 22: 149-157.

Cheng, S. 2003. Heavy metal pollution in China: origin, pattern and control. Environ. Sci. Pollut.Res. Int. 10(3):192-198.

Cogun, H. Y.; Yuzereroglu, T. A.; Firat, O.; Gok, G. and Kargin, F. 2006. Metal concentrations in fish species from the Northeast Mediterranean Sea. Environ. Monit. Assess., 121: 431-438.

Cosson, R. 1994. Heavy metals intracellular balance and relationship with liver of carp after contamination by silver, cadmium and mercury following or not pretreatment by zinc. Bio. Merals., 7: 9-19.

Cusimano, R. F.; Brakke, D. F. and Chapman, G. A. 1986. Effects of $\mathrm{pH}$ on the toxicities of cadmium, copper and zinc to steelhead trout
(Salmo gairdneri). Can. J. Fish Aquat. Sci., 43: 1497-1503.

Farkas, A.; Salanki, J. and Specziar, A. 2003. Ageand size-specific patterns of heavy metals in the organs of freshwater fish Abramis brama L. populating a low-contaminated site. Wat. Res., 37: 959-964.

Ferguson, H. W. 1989. Systemic Pathology of Fish. Lowa State University Press, Ames. IA.

Gingerich, W. H. 1982. Hepatic toxicology of fishes. In: Aquatic Toxicology, Weber, L, Ed. Raven Press, New York, 55.

Gonzalez, R. J.; Grippo, R. S. and Dunson, W. A. 1990. The distribution of sodium balance in brook charr by manganese and iron. J. Fish Biol., 37: 765-774.

Goyer, R. A. 1991. Toxic effects of metals. In: Casarett and Doull's Toxicology: Basic Science of Poisons. $4^{\text {th }}$ edition (eds.Amdur, M. O.; Doul, J. and Klaassen, C.D) Pergamon Press, Oxford, pp.1033.

Heath, A. G. 1987. Water Pollution and Fish physiology. CRC Press, Boca Raton, Fl.

Hibiya, J. 1982. An Atlas of Fish Histology: Normal and Pathological Conditions. Kodasha Ltd., Gustav-Fisher-Verlag, Stuttgard, New York, pp. 82-98.

Hilmy, A. M.; Eldominaty, N. A.; Daabees, A. Y. and Abdel Latief, H. A. A. 1987. Some physiological and biochemical indices of zinc toxicity in two freshwater fishes, Glorias lazera and Tilapia zilli. Comp. Biochem. Physiol., 87C(2): 297-301.

Kwasnik, G. M.; Vetter, R. J. and Atchison, G. J. 1978. The uptake of manganese-54 by green algae (Protococcoidal chlorella), Daphnia magna, and fathead minnows (Pimephales promelas). Hydrobiol., 59: 181-185.

Langston, W. I. 1990. Toxic effects of metals and the incidence of marine ecosystems. In: heavy metals in the marine environment (Eds: Furness RW, Rainbow PS). CRC Press, New York, pp. 256.

Lasheen, M. R. 1987. The distribution of trace metals in Aswan high dam reservoir and river Nile ceoystems. In: Laed, Mercury, Cadmium and Arsenic in the environment. Eds., T.C. Hutchinson and K.M. Meema, 1987 SCOPE, Published by John Wiley and Sons Ltd. 
Leeson, C. R. and Leeson, T. S. 1976. Histology (3 ${ }^{\text {rd }}$ edition). W. B. Saunders Company. Philadelphia, pp. 365-391.

Lindsay, W. L. and Norwell, W. A. 1978. Development of DTPA soil test for zinc, iron, manganese and copper. Soil Sci. Soc. Am. J., Madison, 42: 421-428.

Lloyd, R. 1992. Pollution and freshwater fish. The Buckland foundation. Fishing News Books, Oxford, pp 35-40, 77-81, 107-110, 122-124.

Luna, C. G. 1968. Manual of Histologic Staining Methods of the Armed Forces Institute of Pathology. $3^{\text {rd }}$ Edit., McGraw-Hill Book Compnay, New York.

Mance, G. 1987. Pollution threat of heavy metals in aquatic environments. Elsevier Applied Science, London, pp. 363.

Merian, E. 1991. Metals and their compounds in the environments. Occurrence, analysis and biological relevance. ISBN O-89573-562-8 (VCH New York).

Meyers, T. R. and Hendricks, J. D. 1985. Histopatholgy. In: Fundamentals of Aquatic Toxicology. Methods and Applications (G.M.Rand and S.R. Petrocelli, eds.), Hemisphere Publishing Corp., Washington, DC, pp. 283-331.

Pagenkopf, G. K. 1983. Gill surface interaction model for trace metal toxicity to fish. Role of complexation, $\mathrm{pH}$ and water hardness. Environ. Sci. Technol., 17(6): 342-347.

Peyghan, R.; Razijalaly, M.; Baiat, M. and Rasekh, A. 2003. Study of bioaccumulation of copper in liver and muscle of common carp Cyprinus carpio after copper sulfate bath. Aquacult. Int., 11: 597-604.

Rao, K. J. 1998. Heavy metal inputs to soils by agricultural activities. Env. Geochem. 1: 1518.

Roesijadi, G. and Robinson, W. E. 1994. Metal regulation in aquatic animals: Mechanism of uptake, accumulation and release. In: Aquatic Toxicology; Molecular, Biochemical and Cellular Perspectives. (ed. Malins, D.C, Ostrander, G.K.) Lewis Publishers, London, pp. 539.

Schmitt, C. J. 2004. Concentrations of arsenic, cadmium, copper, lead, selenium and zinc in fish from the Mississippi River basin, 1995. Environ. Monit. Assess. 90:289-321.

Van Dijk, J. P.; Lagerwerf, A.J.; Van Eijk, H.G. and Leijnse, B. 1975. Iron metabolism in the tench (Tinca tinca L.). Studies by means of intravascular administration of ${ }^{59} \mathrm{Fe}$ (III) bound to plasma. J. Comp. Physiol., 99: 321330 .

Velcheva, I. G. 2006. Zinc content in the organs and tissues of freshwater fish from the Kardjali and Studen Kladenets Dam Lakes in Bulgaria. Turk. J. Zool., 30: 1-7.

Vilella, S.; Ingrosso, L.; Lionetto, M.; Schettino, T.; Zonno, V. and Storelli, C. 1999. Effect of cadmium and zinc on the $\mathrm{Na} / \mathrm{H}$ exchanger present on the brush border membrane vesicles isolated from eel kidney tubular cells. Aquat. Toxicol., 48: 25-36.

Walker, R. L. and Fromm, P. O. 1976. Metabolism of iron by normal and iron deficient rainbow trout. Comp. Biochem. Physiol., 55A: 311318.

Whitfield, A. K. and Elliott, M. 2002. Fishes as indicators of environmental and ecological changes with estuaries: a review of progress and some suggestions for the future. J. Fish Biol., 61(1): 220-250.

Wheater, P. R.; Burkitt, H. G.; Stevens, A. and Lowe, J.S. 1985. Basic Histopathology. A Colour Atlas and Text. Churchill Livingstone, New York, pp. 1-4, 116.

Yang, H. N. and Chen, H. C. 1996. Uptake and elimination of cadmium by Japanese eel, Anguilla japonica, at various temperatures. Bull. Environ. Contam. Toxicol., 56: 670676.

Zitko, V. 1979. An equation of lethality curves in tests with aquatic fauna. Chemosphe., 8: 4751.

Zou, E. 1997. Effects of sublethal exposure to zinc chloride on the reproduction of the water flea, Moina irrasa (Cladosera). Bullet. Environ. Contam. Toxicol., 58: 437-441.

Zou, E. and Bu, S. 1994. Acute toxicity of copper, cadmium and zinc to the water flea, Moina irrasa (Cladosera). Bullet. Environ. Contam. Toxicol., 52: 742-748. 